\title{
Protective effect of cinnamon and chamomile extracts as anti- inflammatory on male rats
}

\author{
Maysa, M. Elmallh and *Amr, A. Rezq \\ Nutrition and Food Science Department, Faculty of Home Economics, Helwan \\ University, Cairo, Egypt
}

\begin{abstract}
Cinnamon is a favorite spice around the world because of its health benefits, flavors and preserves food. Chamomile is used to treat various diseases, cancer, diarrhea and healing wound. The present study was conducted to prepared aqueous extracts of cinnamon and chamomile by boiling at $100 \mathrm{C}^{\mathrm{o}}$ and soaking at room temperatures for various periods of times, investigated whether the soaking temperature and time during the preparation of extracts could influence the contents of total phenols and the anti-inflammatory effect of these extracts on male rats. Male albino rats $(n=100)$ weighing $140 \pm 5 \mathrm{~g}$, were used in this study. Anti-inflammatory effect was studied using the formalin $4 \%$ to induce left hind paw edema. Our results found that aqueous extracts prepared by soaking at room temperature at different times were increased in its contents of polyphenols than those prepared by boiling. Orally aqueous cinnamon and chamomile extracts prepared by both boiling and soaking for different times had significant antiinflammatory effects. The decreases in rats paw's thickness after inducing pedal inflammation $(2,4$ and $6 \mathrm{hrs})$ was increased in parallel with boiling or soaking extraction time. Aqueous cinnamon and chamomile extracts prepared by soaking at room temperature had higher anti-inflammatory activity than that prepared by boiling.
\end{abstract}

Keywords: Inflammation-Anti-inflammatory - Cinnamon -Chamomile -
Rats.

\section{1- INTRODUCTION}

Inflammation is the complex biological response of vascular tissues to harmful stimuli, such as pathogens, damaged cells, or irritants (Ferrero-Miliani et al., 2007). Inflammation can be classified as either acute or chronic. Acute inflammation is the initial response of the body to harmful stimuli and is achieved by increased movement of plasma and leukocytes from the blood into the injured tissues. A cascade of biochemical events propagates and matures the inflammatory response, involving the local vascular system, the immune system,

Corresponding author: Amr Abd El-Mordy Rezq

Email: dr.amr_rezq@yahoo.com 
and various cells within the injured tissue. Acute inflammation is a short-term process, usually appearing within a few minutes or hours and ceasing upon the removal of the injurious stimulus (Kumar, 1998). Signs of redness, increased heat, swelling, pain and loss of function (Parakrama et al., 2005) characterize it. However, inflammation that has shows onset and persists for weeks or more is chronic. The symptoms are not as severe as with acute inflammation, but the condition is insidious and persistent. Chronic inflammation may follow on from acute inflammation or exist by itself. An acute inflammation will become chronic if the immune system is unable to rid the body of the offending foreign agent or if the agent is constantly able to reenter the body (Kumar, 1998).

Cinnamon (Cinnamomum cassia) of the family Lauracease is known as Sweet Wood. It is a favorite spice around the world because of its health benefits, flavors and preserves food. It contains medicinally important essential oil in leaves, fruits inner and outer bark. Much of cinnamon's bioactivity resides in its oil, which is about 90\% cinnamaldehyde (Bown, 1995). Cinnamon possess chemopreventive, antispasmodic, sedative, hypothermic, choleretic, antibacterial, antifungal, antipyretic, antiviral, antiplatelet properties, antiseptic, lipolytic, anesthetic, cytotoxic, anodyne, hypolipidemic, and also stimulate immune system that may be useful adjuncts in helping to reduce the risk of cardiovascular disease and cancer (Cralg, 1999). The most favorite chemical constituents of cinnamon are volatile oil (cinnamaldehyde, eugenol, cinnamic acid, and weitherhin), mucilage, diterpenes and proanthocyanidins (Jayaprakasha et al., 2002).

Medicinally, cinnamon is used in the treatment of diarrhea (Skidmore- Roth, 2003), colic and colds, low vitality, poor appetite, rheumatism, kidney weakness and coldness, fevers, arthritic angina, and palpitations. It is externally used as a skin antiseptic to treat minor bacterial and fungal infections of the skin (Aguilar, 1999). Cinnamon bark have a potentiating effect on insulin (Khan et al., 1990) and can be useful in the treatment of type 2 diabetes; as well as lowering triglyceride levels and serum cholesterol (Onderoglu et al., 1999; Broadhurst et al., 2000 and Khan et al., 2003). Some of the plant constituents have shown effects against bacteria and fungi, including the molds that produce the carcinogenic aflatoxins (Juglal et al., 2002; McCann, 2003 and Gruenwald, 2004). It is proven to effective against some species respiratory tract pathogens, including species belonging to the genera Aspergillus, Candida, Cryptococcus and Histoplasma (Viollon and Chaumont, 1994; and Inouye et al., 2001).

Chamomile (Matricaria chamomilla) is used to treat various diseases, cancer (Hernández-Ceruelos et al., 2002), diarrhea (de la Motte et al., 1997), and healing wound (Glowania et al., 1987). Chamomile flowers contain 0.24- to 2.0percent volatile oil that is blue in color. The two enter constituents, (-)-alpha- 
bisabolol and chamazulene account for 50-65 percent of total volatile oil content. Other components of the oil include (-)-alpha-bisabolol oxide A and B, (-)-alphabisabolone oxide A, spiroethers (cis- and trans- en-yndicycloether), sesquiterpenes (anthecotulid), cadinene, farnesene, furfural, spathulenol, and proazulene (matricarin and matricin) (European Pharmacopoeia, 1996).

The constituents of chamomile have antimicrobial properties include alphabisabolol, luteolin, quercetin, and apigenin. Chamomile extracts blocks aggregation of Helicobacter pylori and various strains of Escherichia coli (Annuk et al., 1999) and inhibits the growth of poliovirus and herpes virus. Chamomile esters and lactones demonstrate activity against Mycobacterium tuberculosis and Mycobacterium avium. Chamazulene, alpha-bisabolol, flavonoids, and umbelliferone display antifungal properties against Trichophyton mentagrophytes and Trichophyton rubrum (Turi et al., 1997). Apigenin, alphabisabolol, and the cisspiroethers appear to provide the most significant antispasmodic effects. Other flavonoids and the small amount of coumarins contribute to smooth muscle relaxation (Achterrath-Tuckermann et al., 1980).

In the plant kingdom, nearly all plants are medicinal. Therefore, the present study was conducted to prepared aqueous extracts of cinnamon and chamomile by soaking at $100 \mathrm{C}^{\circ}$ and room temperatures for various periods of times and was used to investigate whether the soaking temperature and soaking time during the preparation of extracts influence the content of total polyphenols and the antiinflammatory effect on male rats.

\section{2- MATERIALS AND METHODS}

\section{1-2- Materials:}

1-2-1- Herbs: Cinnamon (Cinnamomum cassia) and chamomile (Matricaria chamomilla) were purchased as dried material from a local Company for Medicinal Plants and Herbs, Cairo, Egypt.

1-2-2- Animals: Male albino rats $(n=100$ rats), Sprague Dawley strain weighing $140 \pm 5 \mathrm{~g}$, were obtained from the Laboratory Animal Colony, Helwan, Egypt.

1-2-3-Chemicals: Casein, cellulose, vitamin mixture, mineral mixture and formalin were obtained from El-Gomhorya Company for Pharmaceutical and Chemical, Cairo, Egypt.

1-2-4- Drugs: Feldene (Piroxicam) is an anti-inflammatory agent was obtained in the form of ampoules from Pfizer Egypt Company, Cairo, Egypt. 


\section{2-2- Methods:}

\section{2-2-1- Preparation of aqueous extracts:}

The aqueous cinnamon and chamomile extracts were prepared using distilled water (1:10, W/V) as described by Kassi et al., (2004). Extracts were prepared by boiling prepared materials at $100 \mathrm{C}^{\mathrm{o}}$ for different times (i.e. 5, 15, 30, 45 and 60 minutes). Whereas, soaking extracting method was conduct for 3, 6, 9 and 12 hours at room temperature. Then, the aqueous extracts were filtered using cheesecloth and stored at $-4^{\circ} \mathrm{C}$ until used.

\section{2-2-2- Determination of total phenols:}

Total phenols of different aqueous extracts of cinnamon and chamomile were determined by using Spectrophotometer apparatus according to the methods described by Singleton and Rossi, (1965).

\section{2-2-3- Preparation of basal diet:}

The basal diet (AIN-93M) was prepared according to Reeves et al., (1993). It consists of casein $20 \%$, soybean oil $5 \%$, Choline chloride $0.20 \%$, vitamin mixture $1.0 \%$, mineral mixture $4.0 \%$, fibers $5 \%$, L-Cystine $0.18 \%$, sucrose $10 \%$ and the reminder was corn starch.

\section{2-2-4- Experimental design:}

Animals were maintained under standard conditions of humidity, temperature and light (12-h light: 12-h dark cycle), fed on basal diet and water ad libitum for one week before starting the experimental for acclimatization. After acclimatization period (one week), all rats were randomly assigned to study antiinflammatory effect of aqueous cinnamon and chamomile extracts.

Anti-inflammatory study was studied by the method described by Northover and Subramanian, (1962). It depends upon induction of pedal inflammation in rats paw by $0.1 \mathrm{ml}$ of formalin $4 \%$. After acclimatization period (one week), rats $(\mathrm{n}=100)$ were divided as follows:

Group (1): Rats ( $\mathrm{n}=5$ ) were fed on the basal diet only, received orally $1 \mathrm{ml} / 100 \mathrm{~g}$ of saline solution and kept as a positive control.

Group (2): Rats ( $\mathrm{n}=5$ ) were fed on the basal diet only, received orally $1 \mathrm{ml} / 100 \mathrm{~g}$ of saline solution and kept as a standard group.

Group (3): Rats $(n=90)$ were fed on the basal diet and given orally aqueous extracts by tube feeding for seven days at a volume of $1 \mathrm{ml} / 100 \mathrm{~g}$ of body weight. This group was divided into four subgroups as followed: 
Subgroup (1): Divided into five subgroups (five animals each). Each subgroup was given orally aqueous cinnamon extracts prepared by boiling at $100 \mathrm{C}^{\circ}$ for different times $(5,15,30,45$ and 60 min., respectively).

Subgroup (2): Divided into four subgroups (five animals each) and treated with aqueous cinnamon extracts prepared by soaking at room temperature for different times (3, 6, 9 and $12 \mathrm{hrs,} \mathrm{respectively).}$

Subgroup (3): Divided into five subgroups (five animals each) and given orally aqueous extracts of chamomile prepared by boiling at $100 \mathrm{C}^{\circ}$ for different times $(5,15,30,45$ and 60 min., respectively).

Subgroup (4): Divided into four subgroups (five animals each) and given orally aqueous chamomile extracts prepared by soaking at room temperature for different times (3, 6, 9 and $12 \mathrm{hrs,} \mathrm{respectively).}$

At the end of experimental period (7 days), the second group was given (I/P) intraperioteneally Feldene (Piroxicam) as anti-inflammatory drug in a dose of 4 $\mathrm{mg} / \mathrm{kg}$ of body weight. After one hour of the treatment, each rat in all groups was injected with $0.1 \mathrm{ml}$ of formalin $4 \%$ in the plantar side of the left hind paw. The paw thickness caused by formalin was measured using skin caliber immediately and every two hours till 6 hours after injection. The difference between the initial and subsequent reading gave the actual edema volume. Anti-inflammatory effect was assessed by the reduction in the thickness of rat's paw.

\section{2-2-5- Statistical analysis:}

The results were expressed as mean $\pm \mathrm{SE}$ and statistical significance was assessed using one-way analysis of variance (ANOVA) test according to Snedecor and Cochran, (1980).

\section{3- RESULTS AND DISCUSSION}

\section{3-1- Effect of aqueous extraction methods on total phenols contents:}

Total phenols in aqueous cinnamon and chamomile extracts prepared by boiling at $100 \mathrm{C}^{\mathrm{o}}$ and soaking at room temperature for different times are presented in Figures (1 and 2). Results showed that total phenols $(\mathrm{mg} / 100 \mathrm{ml})$ in all aqueous cinnamon extracts were higher than that of all aqueous chamomile extracts. Total phenols in all aqueous extracts were increased with increased extraction time, suggesting that soaking for a long period promoted extraction. This result was seminary agreed with that of Xinguo et al., (2006) who reported that the total polyphenols in tea solutions increased with higher temperatures and longer soaking times. Results also, indicated that extraction by boiling at $100 \mathrm{C}^{\mathrm{o}}$

\section{5}

Corresponding author: Amr Abd El-Mordy Rezq

Email: dr.amr_rezq@yahoo.com 
slightly decreased the total polyphenols content than the extraction by soaking at room temperature for different times. This result suggested that in the extraction at the $100^{\circ} \mathrm{C}$ a small amount of polyphenols was destroyed, or may be reacted with other components to form an insoluble complex or may be oxidized. This notion was proposed when polyphenols were extracted from seeds of Dolichos lablab (Vijayakumari et al., 1995).

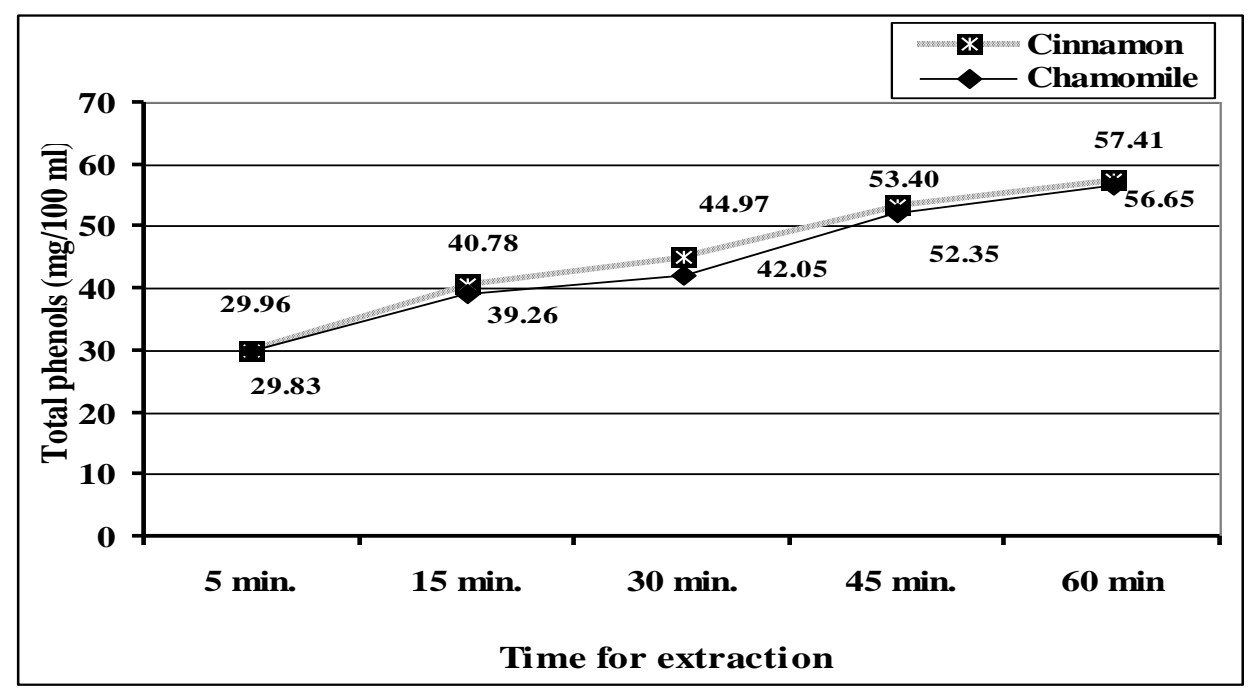

Figure (1): Total phenol content of cinnamon and chamomile extracts prepared by boiling for different times.

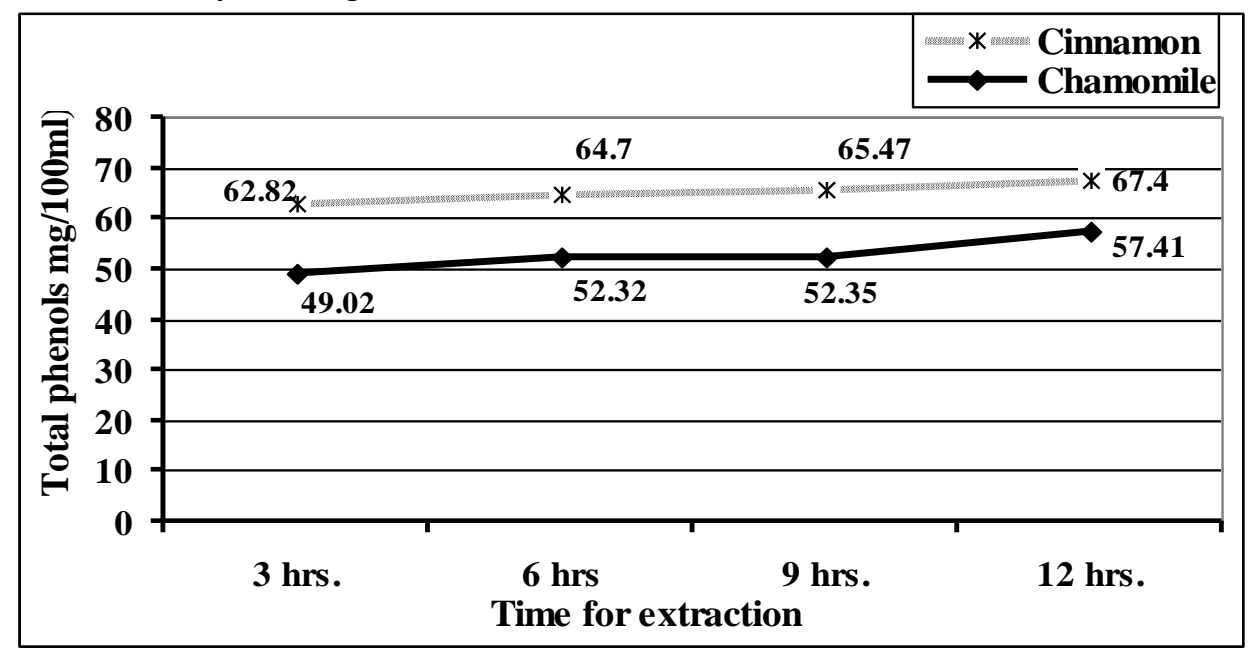

Figure (2): Total phenol contents of cinnamon and chamomile extracts prepared by soaking at room temperature for different times. 


\section{3-2- Anti-inflammatory effect of aqueous cinnamon extracts:}

The effect of aqueous extracts of cinnamon prepared by boiling at $100 \mathrm{C}^{\circ}$ for different times $(5,15,30,45$ and $60 \mathrm{~min})$ on paw's thickness (edema) in rats is shown in Table (1). The obtained results showed that rats given anti-inflammatory agent and rats given orally the aqueous cinnamon extracts at a volume of $1 \mathrm{ml} / 100 \mathrm{~g}$ of body weight had significant anti-inflammatory effect as compared to positive rats, 2, 4 and $6 \mathrm{hrs}$ post administration. Aqueous cinnamon extracts prepared by boiling for 45 and 60 minutes induced significant decreased in paw's thickness in rats as compared with anti-inflammatory agent as well as extraction for 5, 15 and 30 mins, 2 hrs post administration. At four hours post administration; no significant difference was observed in paw's thickness between rats given orally cinnamon extracts and standard group. Rats given orally cinnamon extract prepared by boiling for $5 \mathrm{~min}$. had a significant increase in paw's thickness as compared to those treated with anti-inflammatory agent and with extracts prepared at 30,45 and 60 minutes. There was a significant decrease in paw's thickness of rats given orally extract of cinnamon prepared by boiling for $60 \mathrm{~min}$ as compared to standard group, 6hrs post administration.

Table (1): Effect of aqueous cinnamon extracts prepared by boiling for different times on the paw's thickness of rats.

\begin{tabular}{|c|c|c|c|}
\hline \multirow[b]{2}{*}{ Groups } & \multicolumn{3}{|c|}{ Paw's thickness $(\mathrm{mm})$ as Mean $\pm \mathrm{SE}$} \\
\hline & $2 \mathrm{hr}$ & 4hr & 6hr \\
\hline Positive group & $\begin{array}{r}\mathbf{a} \\
6.60 \pm 0.25\end{array}$ & $\begin{array}{r}\mathbf{a} \\
7.00 \pm 0.32\end{array}$ & $\begin{array}{r}\mathbf{a} \\
7.80 \pm 0.20\end{array}$ \\
\hline Standard group & $\begin{array}{r}\mathbf{b} \\
5.80 \pm 0.20\end{array}$ & $\begin{array}{r}\mathbf{b} \\
4.60 \pm 0.25\end{array}$ & $\begin{array}{r}\text { cd } \\
3.80 \pm 0.20\end{array}$ \\
\hline $\begin{array}{l}\text { Treated groups } \\
\text { Boiling time } \\
5 \mathrm{~min} .\end{array}$ & $\begin{array}{r}\mathbf{b} \\
5.60 \pm 0.19 \\
\end{array}$ & $\begin{array}{r}\mathbf{b} \\
4.80 \pm 0.30 \\
\end{array}$ & $\begin{array}{r}\mathbf{b} \\
4.40 \pm 0.19 \\
\end{array}$ \\
\hline $15 \mathrm{~min}$. & $\begin{array}{r}\mathbf{b} \\
5.30 \pm 0.12 \\
\end{array}$ & $\begin{array}{r}\mathbf{b} \\
4.80 \pm 0.26 \\
\end{array}$ & $\begin{array}{r}\mathbf{b c} \\
4.20 \pm 0.12 \\
\end{array}$ \\
\hline $30 \mathrm{~min}$. & $\begin{array}{r}\mathbf{b} \\
5.30 \pm 0.20 \\
\end{array}$ & $\begin{array}{r}\mathbf{b} \\
4.60 \pm 0.25 \\
\end{array}$ & $\begin{array}{r}\text { cd } \\
3.80 \pm 0.20 \\
\end{array}$ \\
\hline $45 \mathrm{~min}$. & $\begin{array}{r}\mathbf{c} \\
4.60 \pm 0.25 \\
\end{array}$ & $\begin{array}{r}\mathbf{b} \\
4.00 \pm 0.22 \\
\end{array}$ & $\begin{array}{r}\text { de } \\
3.40 \pm 0.25 \\
\end{array}$ \\
\hline $60 \mathrm{~min}$. & $\begin{array}{r}\mathbf{c} \\
4.40 \pm 0.25\end{array}$ & $\begin{array}{r}\mathbf{b} \\
4.00 \pm 0.32\end{array}$ & $\begin{array}{c}\mathbf{e} \\
3.20 \pm 0.12\end{array}$ \\
\hline
\end{tabular}

-Different superscript letters in the same column denotes significant differences $(p<0.05)$.

- SE: Standard Error. 
With regard to the anti-inflammatory effect of aqueous cinnamon extracts prepared by soaking at room temperature for different times on the paw's thickness of rats after induced pedal inflammation, results is recorded in Table (2). Results revealed that the anti-inflammatory agent not induced a significant anti-inflammatory effect as compared to positive group, $2 \mathrm{hrs}$ post administration. The aqueous cinnamon extracts caused a significant anti-inflammatory effect as compared to anti-inflammatory agent and positive group after 2 hours of induced pedal inflammation. There was a significant decrease in paw's thickness of all rats given orally cinnamon extracts and standard rats given anti-inflammatory agent as compared to positive group, 4 and $6 \mathrm{hrs}$ post administrations. However, there were not significant differences in paw's thickness between rats given orally soaking aqueous cinnamon extracts and those given anti-inflammatory agent, 4 and 6hrs post administration. From the obtained data, it could be concluded that extraction for $60 \mathrm{~min}$ at $100 \mathrm{C}^{\circ}$ and for $12 \mathrm{hrs}$ at room temperature had the best results.

Table (2): Effect of aqueous cinnamon extracts prepared by soaking at room temperature for different times on the paw's thickness of rats.

\begin{tabular}{|c|c|c|c|}
\hline \multirow[b]{2}{*}{ Groups } & \multicolumn{3}{|c|}{ Paw's thickness $(\mathrm{mm})$ as Mean $\pm \mathrm{SE}$} \\
\hline & $2 \mathrm{hr}$ & $4 \mathrm{hr}$ & $6 \mathrm{hr}$ \\
\hline Positive group & $6.60 \pm 0.25$ & $\begin{array}{r}\mathbf{a} \\
7.00 \pm 0.32 \\
\end{array}$ & $7.80 \pm 0.20$ \\
\hline Standard group & $\begin{array}{r}\mathbf{a} \\
5.80 \pm 0.20\end{array}$ & $\begin{array}{r}\mathbf{b} \\
4.60 \pm 0.25\end{array}$ & $\begin{array}{r}\mathbf{b} \\
3.80 \pm 0.20\end{array}$ \\
\hline $\begin{array}{l}\text { Treated groups } \\
\text { Soaking time } \\
3 \mathrm{hr} .\end{array}$ & $\begin{array}{r}\mathbf{b} \\
4.80 \pm 0.37 \\
\end{array}$ & $\begin{array}{r}\mathbf{b} \\
4.20 \pm 0.20 \\
\end{array}$ & $\begin{array}{r}\mathbf{b} \\
4.00 \pm 0.16 \\
\end{array}$ \\
\hline $6 \mathrm{hr}$. & $\begin{array}{r}\mathbf{b} \\
4.80 \pm 0.37 \\
\end{array}$ & $\begin{array}{r}\mathbf{b} \\
4.10 \pm 0.19 \\
\end{array}$ & $\begin{array}{r}\mathbf{b} \\
4.00 \pm 0.36 \\
\end{array}$ \\
\hline 9 hr. & $\begin{array}{r}\mathbf{b} \\
4.40 \pm 0.19 \\
\end{array}$ & $\begin{array}{r}\mathbf{b} \\
4.00 \pm 0.22 \\
\end{array}$ & $\begin{array}{r}\mathbf{b} \\
3.60 \pm 0.25 \\
\end{array}$ \\
\hline $12 \mathrm{hr}$. & $4.20 \pm 0.26$ & $\begin{array}{r}\mathbf{b} \\
3.80 \pm 0.37\end{array}$ & $\begin{array}{r}\mathbf{b} \\
3.40 \pm 0.25\end{array}$ \\
\hline
\end{tabular}

-Different superscript letters in the same column denotes significant differences $(p<0.05)$.

- SE: Standard Error.

In generally, results in Tables (1 and 2) revealed that the aqueous cinnamon extracts prepared by boiling at $100 \mathrm{C}^{\mathrm{o}}$ and soaking at room temperature for different times has a strong anti-inflammatory effect. This result was in 
accordance with those of Atta and Alkofahi, (1998) who showed cinnamon possess an anti-inflammatory effect against acute (xylene-induced ear oedema) and chronic (cotton-pellet granuloma) inflammation in rats. Inflammation induced by formalin may be related to a biphasic phenomenon. The first phase of edema is attributed to release of histamine and 5-hydroxytryptamine and second accelerating phase of swelling is attributed to prostaglandin like substances. The enzyme, phospholipase A2, is known to be responsible for the formation prostaglandins and leukotrienes as mediators of inflammation, which by attracting polymorphonuclear leucocytes to the site of inflammation would lead to tissue damage, probably by the release of free radicals. Phospholipase A2 converts phospholipids in the cell membrane into arachidonic acid, which is highly reactive and is rapidly metabolized by cycloxygenase (prostaglandin synthase) to prostaglandins, which are major components that induce pain and inflammation (Higgs et al., 1984). Mechanism of anti-inflammatory effect of aqueous cinnamon extracts may be explained on basis of the inhibition of prostaglandins and the release of histamine. These results agreed with Jonathan et al., (2008) who reported that cinnamon extract had significant effect in the inhibition of histamine release and synthesis of lipid-derived mediators. Cinnamon extract had a mixture of polymeric polyphenols (Anderson et al., 2004) which has a potential role in regulating immune function (Cralg, 1999), reduce inflammation (Ames et al., 1993 and Willett, 1994) and possess antioxidant action that may prove beneficial against free radical damage to cell membranes (Lee and Shibamoto, 2002). Tristetraprolin (TTP/zinc finger protein 36) family proteins had anti-inflammatory effects by destabilizing proinflammatory mRNA. TTP was caused by the effect of polyphenols extract of cinnamon in adipocytes (Heping et al., 2008). Our data also found that, cinnamon aqueous extracts prepared by soaking at room temperature for different time had anti-inflammatory effect more than that prepared by boiling at $100 \mathrm{C}^{\circ}$ for different times. These results may be explained on basis the higher content of total phenols and volatile oils in cinnamon aqueous extracts prepared by soaking at room temperature which had much of cinnamon's bioactivity (Bown, 1995). The constituents of volatile oil (cinnamaldehyde, eugenol, cinnamic acid and weitherhin), mucilage, diterpenes, and proanthocyanidins had antioxidant action which may prove beneficial against free radical damage to cell membranes (Jayaprakasha et al., 2002; Lee and Shibamoto, 2002 and Dragland et al., 2003).

\section{3-3- Anti-inflammatory effect of aqueous chamomile extracts:}

The effect of aqueous chamomile extracts prepared by boiling at $100 \mathrm{C}^{\mathrm{o}}$ for different times $(5,15,30,45$ and $60 \mathrm{~min})$ on the paw's thickness in rats is shown in Table (3). Results showed that the anti-inflammatory agent and the aqueous 
chamomile extracts had significant anti-inflammatory effects as compared to positive group, 2, 4 and $6 \mathrm{hrs}$ post administration. There were no significant differences in paw's thickness between groups given orally aqueous chamomile extracts $(1 \mathrm{ml} / 100 \mathrm{~g}$ of body weight $)$ and those given anti-inflammatory drug after 2, 4 or $6 \mathrm{hrs}$ of induced pedal inflammation.

Table (3): Effect of aqueous chamomile extracts prepared by boiling at $100 \mathrm{C}^{\mathrm{o}}$ for different times on the paw's thickness of rats.

\begin{tabular}{|c|c|c|c|}
\hline \multirow[b]{2}{*}{ Groups } & \multicolumn{3}{|c|}{ Paw's thickness $(\mathrm{mm})$ as Mean $\pm \mathrm{SE}$} \\
\hline & $2 \mathrm{hr}$ & $4 \mathrm{hr}$ & $6 \mathrm{hr}$ \\
\hline Positive group & $6.60 \pm 0.25$ & $7.00 \pm 0.32$ & $\begin{array}{r}\mathbf{a} \\
7.80 \pm 0.20\end{array}$ \\
\hline Standard group & $\begin{array}{r}\mathbf{b} \\
5.80 \pm 0.20\end{array}$ & $\begin{array}{r}\mathbf{b} \\
4.60 \pm 0.25\end{array}$ & $\begin{array}{r}\mathbf{b} \\
3.80 \pm 0.20\end{array}$ \\
\hline $\begin{array}{l}\text { Treated groups } \\
\text { Boiling time } \\
5 \mathrm{~min} .\end{array}$ & $\begin{array}{r}\mathbf{b} \\
5.40 \pm 0.25 \\
\end{array}$ & $\begin{array}{r}\mathbf{b} \\
4.80 \pm 0.20 \\
\end{array}$ & $\begin{array}{r}\mathbf{b} \\
4.00 \pm 0.00 \\
\end{array}$ \\
\hline $15 \mathrm{~min}$. & $\begin{array}{r}\mathbf{b} \\
5.30 \pm 0.30\end{array}$ & $\begin{array}{r}\mathbf{b} \\
4.60 \pm 0.25\end{array}$ & $\begin{array}{r}\mathbf{b} \\
4.00 \pm 0.00\end{array}$ \\
\hline $30 \mathrm{~min}$. & $5.20 \pm 0.20$ & $\begin{array}{r}\mathbf{b} \\
4.60 \pm 0.25\end{array}$ & $\begin{array}{r}\mathbf{b} \\
3.70 \pm 0.30\end{array}$ \\
\hline $45 \mathrm{~min}$. & $\begin{array}{r}\mathbf{b} \\
5.20 \pm 0.20\end{array}$ & $\begin{array}{r}\mathbf{b} \\
4.50 \pm 0.32\end{array}$ & $\begin{array}{r}\mathbf{b} \\
3.60 \pm 0.25\end{array}$ \\
\hline $60 \mathrm{~min}$. & $5.20 \pm 0.20$ & $\begin{array}{r}\mathbf{b} \\
4.40 \pm 0.25\end{array}$ & $\begin{array}{r}\mathbf{b} \\
3.40 \pm 0.25\end{array}$ \\
\hline
\end{tabular}

-Different superscript letters in the same column denotes significant differences $(p<0.05)$.

- SE: Standard Error.

As shown in Table (4) results revealed that anti-inflammatory agent and aqueous chamomile extracts prepared by soaking at room temperature for different times $(3,6,9$ and $12 \mathrm{hrs}$.) induced significant decreased in paw's thickness of rats after induction of pedal inflammation as compared to positive group, 2, 4 and $6 \mathrm{hrs}$ post administration. Aqueous chamomile extracts prepared by soaking for 6,9 and $12 \mathrm{hrs}$ had significant anti-inflammatory effect after $2 \mathrm{hrs}$ of induced pedal inflammation as compared to anti-inflammatory drug. There was no significant differences in paw's thickness in rats given orally aqueous extracts and those given anti-inflammatory agent, 4 and $6 \mathrm{hrs}$ post administration. The anti-inflammatory effect of aqueous chamomile extracts prepared by soaking for $12 \mathrm{hrs}$ was significantly increased as compared to standard inflammatory drug, 6 hrs post administration. 
Table (4): Effect of aqueous chamomile extracts prepared by soaking at room temperature for different times on the paw's thickness of rats.

\begin{tabular}{|c|c|c|c|}
\hline \multirow[b]{2}{*}{ Groups } & \multicolumn{3}{|c|}{ Paw's thickness $(\mathrm{mm})$ as Mean $\pm \mathrm{SE}$} \\
\hline & $2 \mathrm{hr}$ & $4 \mathrm{hr}$ & $6 \mathrm{hr}$ \\
\hline Positive group & $\begin{array}{r}\mathbf{a} \\
6.60 \pm 0.25 \\
\end{array}$ & $\begin{array}{r}\mathbf{a} \\
7.00 \pm 0.32 \\
\end{array}$ & $\begin{array}{r}\mathbf{a} \\
7.80 \pm 0.20 \\
\end{array}$ \\
\hline Standard group & $\begin{array}{r}\mathbf{b} \\
5.80 \pm 0.20 \\
\end{array}$ & $\begin{array}{r}\mathbf{b} \\
4.60 \pm 0.25 \\
\end{array}$ & $\begin{array}{r}\mathbf{b} \\
3.80 \pm 0.20 \\
\end{array}$ \\
\hline $\begin{array}{l}\text { Treated groups } \\
\text { Soaking time } \\
3 \mathrm{hr} \text {. }\end{array}$ & $\begin{array}{r}\mathbf{b c} \\
5.40 \pm 0.19\end{array}$ & $\begin{array}{r}\mathbf{b} \\
4.60 \pm 0.19\end{array}$ & $\begin{array}{r}\mathbf{b} \\
4.20 \pm 0.12\end{array}$ \\
\hline $6 \mathrm{hr}$. & $\begin{array}{r}\text { cd } \\
5.20 \pm 0.20\end{array}$ & $\begin{array}{r}\mathbf{b} \\
4.40 \pm 0.25\end{array}$ & $\begin{array}{r}\mathbf{b} \\
4.10 \pm 0.01\end{array}$ \\
\hline 9 hr. & $\begin{array}{r}\text { cd } \\
5.20 \pm 0.12\end{array}$ & $\begin{array}{r}\mathbf{b} \\
4.20 \pm 0.20\end{array}$ & $\begin{array}{r}\mathbf{b} \\
3.80 \pm 0.26\end{array}$ \\
\hline $12 \mathrm{hr}$. & $\begin{array}{r}\mathbf{d} \\
4.80 \pm 0.12\end{array}$ & $\begin{array}{r}\mathbf{b} \\
4.00 \pm 0.16\end{array}$ & $\begin{array}{r}\mathbf{c} \\
3.20 \pm 0.12\end{array}$ \\
\hline
\end{tabular}

-Different superscript letters in the same column denotes significant differences $(p<0.05)$.

- SE: Standard Error.

Generally results indicated aqueous chamomile extracts prepared by boiling at $100 \mathrm{C}^{\mathbf{o}}$ and soaking at room temperature for different times had significant antiinflammatory effect. Anti-inflammatory effect of aqueous chamomile extracts was increased by increasing time of extraction. These results may be explained on basis the content of total phenols, which increased with increasing extraction time. These results agreed with those of Hernandez-Ceruelos et al., (2002), who reported that chamomile (Matricaria chamomilla) is used to treat various diseases such as inflammation and cancer. Chamomile was found to be effective as hydrocortisone and demonstrated superior activity to bufexamac and fluocortin butyl ester (Aertgeerts et al., 1985). In vitro, chamomile extract inhibits both cyclooxygenase and lipoxygenase, and consequently prostaglandins and leukotrienes (Hormann and Korting, 1994). Anti-inflammatory effect of aqueous chamomile extracts could be attributed to its components. Azulenes (chamazulene, prochamazulene, and guaiazulene) influence on the pituitary and adrenals, increasing cortisone release and reducing histamine release (Berry, 1995). Flavonoids, including apigenin, chamazulene and $\alpha$-bisabolol contents in whole plant chamomile extract. The flavones act as anti-inflammatory agents due to interfering with the arachidonic acid pathway (Hadly and Petry, 1999). Salicylic acid in the form of a methyl ester provides an anti-inflammatory effect (Pistorius et al., 2003). 
Data also revealed that aqueous chamomile extracts prepared by soaking at room temperature for different times had strong anti-inflammatory effect as compared to boiling at $100 \mathrm{C}^{\mathrm{o}}$. These results may be related to the higher content of polyphenols and the presence of volatile oil in these extracts, which may be destroyed by heat. This result accorded with Szelenyi and Isaac, (1979) who reported that the high alpha-bisabolol contents in chamomile oil provide the majority of anti-inflammatory. Polyphenols may reduce inflammation and stimuli immune system (Ascherio et al., (1992) and Dragsted et al., (1993).

\section{4- REFERENCES}

1- Achterrath-Tuckermann, U., Kunde, R. and Flaskamp, E. (1980). Pharmacological investigations with compounds of chamomile. Investigations on the spasmolytic effect of compounds of chamomile and Kamillosan on the isolated guinea pig ileum. Planta Med; 39:38-50.

2- Aertgeerts, P., Albring, M. and Klaschka, F. (1985). Comparative testing of Kamillosan cream and steroidal and non-steroidal dermatologic agents in maintenance therapy of eczematous diseases. Z. Hautkr; 60:270-277.

3- Aguilar, A. (1999). Plantas Medicinales del Centro de Mexico. Mexico City: Guias Practicas Mexico Desconocido.

4- Ames, B.M., Shigena, M.K., Hagen, T.M. (1993). Oxidants, antioxidants and the degenerative diseases of aging. Proceedings of the National Academy of Sciences (USA); 90: 7915-7922.

5- Anderson, R. A., Broadhurst, C. L., Polansky, M. M., Schmidt, W. R., Khan, A. and Flanagan, V. P. (2004). Isolation and characterization of polyphenols polymers from cinnamon with insulin-like biological activity. J. Agric. Food Chem; 52: 65-70.

6- Annuk H, Hirmo S, Turi E. (1999). Effect on cell surface hydrophobicity and susceptibility of Helicobacter pylori to medicinal plant extracts. FEMS Microbiol Lett; 172:41-45.

7- Ascherio, A., Rimm, E. B., Giovannucci, E. L., Colditz, G. A., Rosner, B., Willett, W. C., Sacks, F., Stampfer, M. J., (1992). A prospective study of nutritional factors and hypertension among U S men. Circulation; 86: 1475-1484.

8- Atta A. and Alkofahi, A. (1998). Anti-nociceptive and anti-inflammatory effects of some Jordanian medicinal plant extracts. J. Ethnopharmacol; 60(2):117-24. 
9- Berry, M. (1995). The chamomiles. Pharm. J; 254: 191- 193.

10- Bown, D. (1995). The royal horticultural society encyclopedia of herbs and their uses. Dorling Kindersley Ltd. London. Pp. 424.

11- Broadhurst, C. L., Polansky, M. M. and Anderson, R. A. (2000). Insulinlike biological activity of culinary and medicinal plant aqueous extracts in vitro. J. Agric Food Chem; 48(3):849-852.

12- Cralg, W.J. (1999). Health-promoting properties of common herbs. Amer. J. Clin. Nutr; 70(3): 4915-4995.

13- de la Motte, S., Bose, O., Reilly, S., Heinisch, M. and Harrison F. (1997). Double-blind comparison of an apple pectin-chamomile extracts preparation with placebo in children with diarrhea. Arzneimittelforschung; 47: 1247-1249.

14- Dragland, S., Senoo, H. and Wake, K. (2003). Several culinary and medicinal herbs are important sources of dietary antioxidants. Nutr; 133(5):1286-1290.

15- Dragsted, L., Strube, M. and Larsen, J. (1993). Cancer-protective factors in fruits and vegetables: biochemical and biological background. Pharm. Toxico; 72 (1): 116-135.

16- Ferrero-Miliani, L., Nielsen, O. H., Andersen, P. S. and Girardin, S. E. (2007). Chronic inflammation: importance of NOD2 and NALP3 in interleukin-1beta generation. Clin. Exp. Immunol; 147 (2): 227 235.

17- Glowania, H. J., Raulin, C. and Swoboda, M. (1997). Effect of chamomile on wound healing - a clinical doubleblind study. Z. Hautkr; 62:1262-1271.

18- Gruenwald, J. (2004). PDR for Herbal Medicines 3 rd ed. Montvale, NJ: Thompson PDR; Pp. 199-200.

19- Hadly, S. and Petry, J. (1999). Medicine herbs: a primer for primary care. Hosp. Pract; 34: 109-112.

20- Hernández-Ceruelos, A. E., Madrigal, B. and de la Cruz, C. (2002). Inhibitory effect of chamomile essential oil on the sister chromatid exchanges induced by daunorubicin and methyl methanesulfonate in mouse bone marrow. Toxicology Letters; 135: 103-110.

21- Heping, C., Joseph, F., Urban J. and Richard A. (2008). Cinnamon polyphenol extract affects immune responses by regulating antiand proinflammatory and glucose transporter gene expression in mouse macrophages. J. of Nutr; 138: 833-840 
22- Higgs, G., Moncada, S. and Vane, J. (1984). Eicosanoids in inflammation, Ann Clin Res; 16:287-299.

23- Hormann, H. and Korting, H. (1994). Evidence for the efficacy and safety of topical herbal drugs in dermatology: part 1: anti-inflammatory agents. Phytomedicine; 1:161-171.

24- Inouye, S., Yamaguchi, H. and Takizawa, T. (2001). Screening of the antibacterial effects of a variety of essential oils on respiratory tract pathogens, using a modified dilution assay method. J Infect Chemother; 7(4):251-254.

25- Jayaprakasha, G. K., Raom, L. J. and Sakariah, K. K. (2002). Chemical composition of volatile oil from Cinnamomum zeylanicum buds. Z Naturforsch [C]; 57(11-12):990-993.

26- Jonathan, C., Marc, L., Yumei, L., Lisa, R. and Randolph, K. (2008). Clinical and biochemical effects of a combination botanical product (ClearGuard ${ }^{\mathrm{TM}}$ ) for allergy: a pilot randomized doubleblind placebo-controlled trial. Nutri. J., 7: p20.

27- Juglal, S., Govinden, R. and Odhav, B. (2002). Spice oils for the control of co-occurring mycotoxinproducing fungi. Food Prot.; 65(4):683687.

28- Khan, A., Bryden, N. A., Polansky, M. M. and Anderson, R. A. (1990). Insulin potentiating factor and chromium content of selected foods and spices. Biol Trace Elem Res; 24(3):183-188.

29- Khan, A., Safdar, M., Ali Khan, M., Khattak, K. and Anderson R. (2003). Cinnamon improves glucose and lipids of people with type 2 diabetes. Diabetes Care; 26(12):3215-3218.

30- Kumar, C. (1998). Robbins Pathologic Basis of Disease. Philadelphia: W.B Saunders Company.

31- Lee, K. G. and Shibamoto, T. (2002). Determination of antioxidant potential of volatile extracts isolated from various herbs and spices. J Agric Food Chem; 50(17):4947-4952.

32- McCann, J. (2003). Herbal Medicine Handbook $2^{\text {nd }}$ ed. Philadelphia: Lippincott.

33- Kassi, E., Papoutsi, Z., Fokialakis, N. (2004). Greek plant extracts exhibit selective estrogen receptor modulator (SERM)-like properties. J Agric Food Chem 52: 6956-6961.

34- Northover, B. and Subramanian, G. (1962). Pedal inflammation induced by chemical agents. Br. J. Pharmacol; 18: 346-349.

Corresponding author: Amr Abd El-Mordy Rezq

Email: dr.amr_rezq@yahoo.com 
35- Onderoglu, S., Sozer, S., Erbil, K., Ortac, R. and Lermioglu, F. (1999). The evaluation of long-term effects of cinnamon bark and olive leaf on toxicity induced by streptozotocin administration to rats. $\mathbf{J}$ Pharm Pharmacol; 51(11):1305-1312.

36- Parakrama, C., Clive, R. and Taylor, C. (2005). The acute inflammatory response, sub-section cardinal clinical signs. Part A. General Pathology, Section II. The Host Response to Injury, Chapter 3. Concise Pathology $3^{\text {rd }}$. New York, N.Y.: McGraw-Hill.

37- Reeves, P. G., Nielson, F. H. and Fahmy, G. C. (1993): Reports of the American Institute of Nutrition, adhoc wiling committee on reformulation of the AIN 93. Rodent Diet J. Nutri; 123: 19391951.

38- Snedecor, G. W. and Cochran, W. G. (1980). Statistical methods, $7^{\text {th }}$ Ed Ames, Iowa State University Press, USA; pp 39-63.

39- Skidmore-Roth, L. (2003). Handbook of Herbs and Natural Supplements $2^{\text {nd }}$ Ed. St. Louis: Mosby.

40- Singleton, V. L. and Rossi, C. (1965). Colormetry of total phenol with phosphomolybdic phosphotungstic acid reagent. Amr. J. Eno. Viticultre; 16: 149-158.

41- Szelenyi, I. and Isaac, O. (1979). Thiemer K. Pharmacological experiments with compounds of chamomile. III. Experimental studies of the ulcer protective effect of chamomile. Planta Med; 35:218-227.

42- Turi, M., Turi, E., Koljalg, S. and Mikelsaar, M. (1997). Influence of aqueous extracts of medicinal plants on surface hydrophobicity of Escherichia coli strains of different origin. APMIS; 105: 956-962.

43- Vijayakumari, K., Siddhuraju, P., Janardhanan, K., (1995). Effects of various water or hydrothermal treatments on certain antinutritional compounds in the seeds of the tribal pulse, Dolichos lablab var. vulgaris L. Plant Foods Hum. Nutr; 48: 17-29.

44- Viollon, C. and Chaumont, J. (1994). Anti-fungal properties of essential oils and their main components upon Cryptococcus neoformans. Mycopathologia; 128(3):151-153.

45- Willett, C. W., (1994). Micronutrients and cancer risk. Amr. J. Cli. Nutri. 59:162-165.

46- Xinguo, S., Jun, D., Yueming, J., John, S. and Yukio, K. (2006). Effects of soaking conditions on the antioxidant potentials of oolong tea. J. Food Composition and Analysis; 19: 348-353. 


\section{التأثير الواقي لمستخلص القرفه والبابونج كمضاد للالتهاب في ذكور الفئران

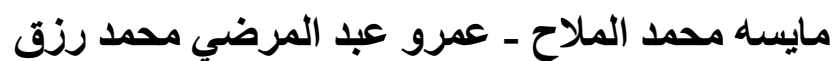 \\ قسم التغذبه و علوم الاطعمهــ كلية الاقتصاد المنزلي- جامعة حلوان}

\section{المستخلص}

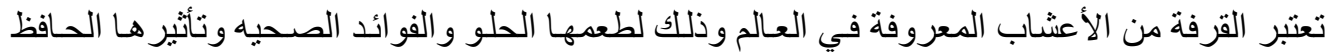

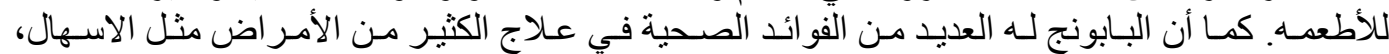

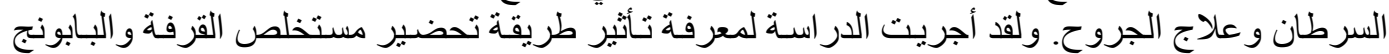

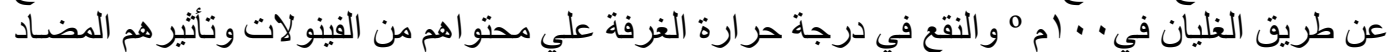

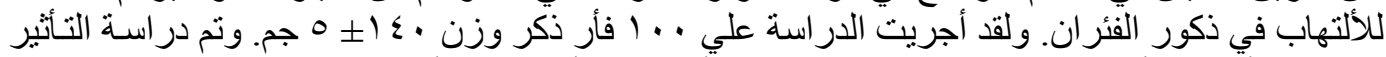

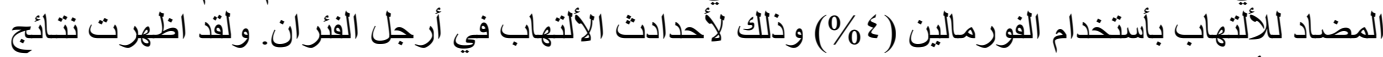

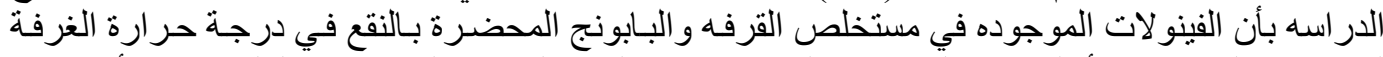

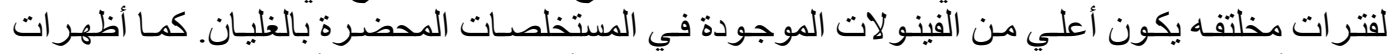

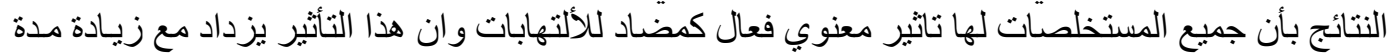

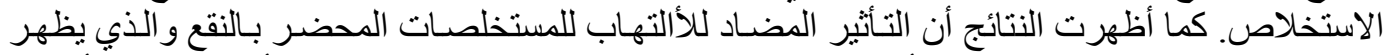

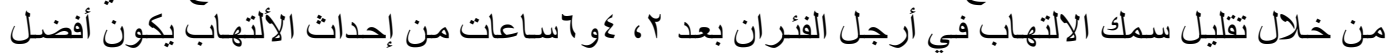

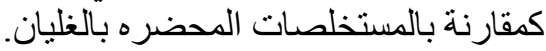
الكلمات المفتاحيه: الالتهابات ـ مضادات الالتهاب ـ القرفه ـ البابونج - الفئران.

الاميلdr.amr_rezq@yahoo.com 